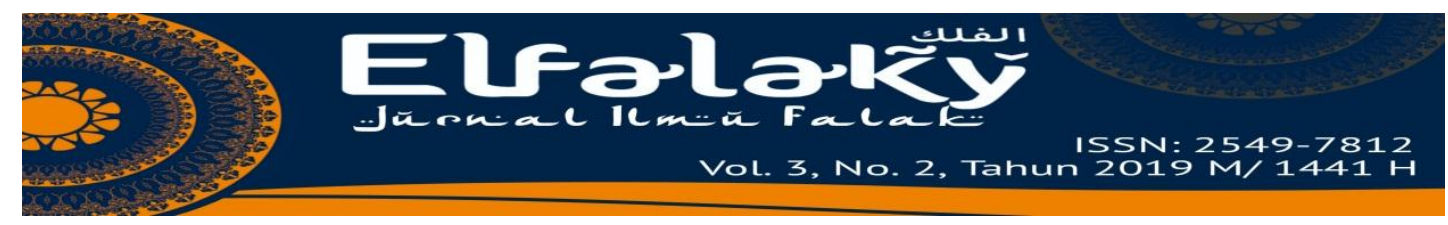

\title{
UJI AKURASI PENENTUAN DEKLINASI MATAHARI DENGAN MENGGUNAKAN I-ZUN DIAL Iqbal Kamalludin
}

\author{
Jurusan Hukum Keluarga Islam Fakultas Syariah IAIN Pekalongan \\ Email : kamalludin.iqbal@gmail.com
}

\begin{abstract}
Abstrak
Tulisan ini mengkaji tentang uji akurasi deklinasi matahari yang merupakan salah satu data syarat untuk menentukan waktu sholat, titik koordinat tempat, rukyatul hilal dengan menggunakan I-zun Dial. Salah satu alat untuk menentukan deklinasi Matahari pada era kontemporer adalah penemuan baru karya $M$. Ihtirozun Ni'am yang bernama I-zun Dial. Penelitian ini dilakukan untuk menjawab bagaimana metode penentuan deklinasi Matahari dengan menggunakan I-zun Dial dan relevansinya jika diimplementasikan, serta bagaimana akurasi metode penentuan deklinasi Matahari dengan menggunankan I-zun Dial. Jenis penelitian ini adalah penelitian kualitatif. Hasil penelitian ini menunjukkan metode penentuan deklinasi Matahari dengan menggunakan I-zun Dial. Dilihat dari cara penggunaannya, dalam metode ini, harus terlebih dahulu diketahui titik koordinat tempat, waktu kulminasi, titik arah utara sejati, dan jarak zenith Matahari dengan bantuan gnomon dan satuan ukuran sentimeter pada bidangnya, sehingga praktis dan mempermudah penggunanya. Akurasi metode penentuan deklinasi Matahari menggunakan I-zun Dial dikategorikan akurat, karena jika hasilnya dibandingkan, data deklinasi Matahari yang ditampilkan Izun Dial, Almanak Nautika dan Ephemeris setelah melalui proses pengujian menunjukkan selisih yang hanya berbeda pada nilai menitnya saja, dibuktikan dengan kesepuluh uji coba dalam penelitian ini, semuanya menunjukkan selisih menit.
\end{abstract}

Keywords: Uji Akurasi, Deklinasi dan I-zun Dial

\section{Pendahuluan}

Kebutuhan manusia untuk mengetahui ukuran waktu yang tepat semakin lama semakin berkembang. Manusia mulai menemukan berbagai alat untuk mengukur waktu, seperti jam pasir, jam air dan sun-dial (jam Matahari). Alatalat tersebut ditemukan agar manusia bisa mengetahui ukuran waktu yang tepat sehingga mereka bisa mengatur kegiatan mereka dengan lebih teratur.

Zaman yang semakin berkembang memudahkan manusia untuk mempelajari benda-benda langit. Beberapa alat yang digunakan untuk keperluan 
pengamatan benda langit diantaranya adalah teropong Vixen, Theodolite, Mizwala, Sun-dial yang sudah dikenal dan tinggi tingkat akurasinya. Hal ini semakin mempermudah manusia dalam berijtihad terkait dengan hal-hal yang bersifat ibadah.

Lain halnya dengan alat-alat diatas yang sudah lama ditemukan dan sudah mengalami uji akurasi, terdapat satu alat penemuan baru yang juga diperuntukkan untuk mempelajari benda-benda langit yaitu I-zun Dial. I-zun Dial merupakan salah satu alat falak praktis kontemporer yang dapat dipergunakan untuk: perhitungan trigonometri ( $\sin , \cos , \tan$ ); menentukan arah utara sejati; menentukan nilai deklinasi Matahari; menentukan ketinggian benda langit (Matahari, Bulan, Venus, dll); menentukan awal waktu shalat; menentukan lintang dan bujur tempat; melakukan rukyatul hilal (bagi I-zun Dial dengan bahan akrilik); menentukan ketinggian benda, seperti menara, dll.

Alat praktis ini ditemukan oleh M. Ihtirozun Ni'am. Pemilihan I-zun Dial dalam penelitian ini dikarenakan alat ini merupakan alat penemuan baru dan cukup praktis untuk dibawa kemana-mana, selain itu juga tidak terpengaruh oleh radiasi magnetik dalam pengoperasiannya. Fungsinya yang cukup banyak, juga memungkinkan alat ini akan banyak digunakan kedepannya oleh masyarakat terutama pegiat falak.

Bentuk I-zun Dial adalah persegi/kotak dengan memakai satuan sentimeter karena memanfaatkan panjang sisi depan (aturan segitiga). Berbeda dengan halnya Mizwala dan Istiwa'aini yang mempunyai bentuk lingkaran dengan mempergunakan satuan derajat di dalamnya. 


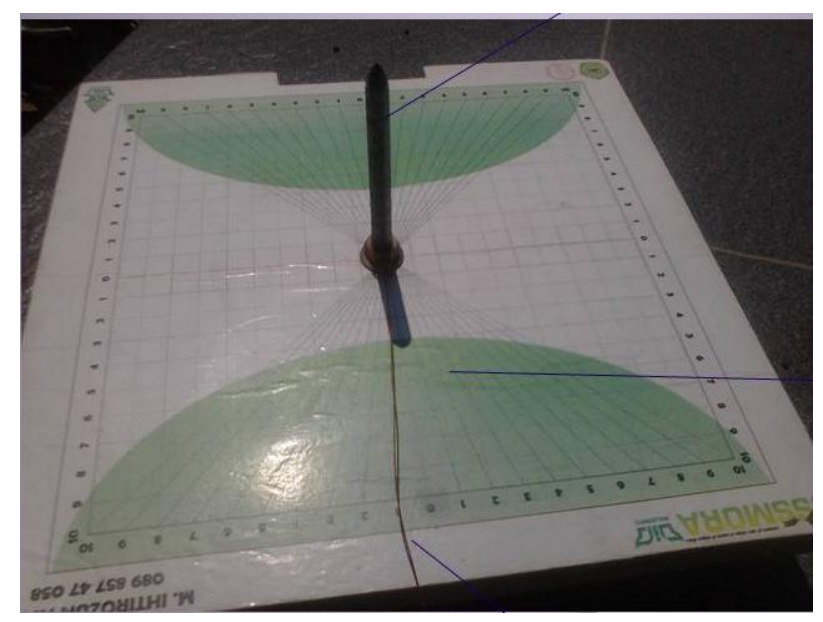

Gambar 1. I-zun Dial

I-zun Dial mempunyai dua bidang yang bisa dimanfaatkan, salah satunya merupakan penyempurnaan dari konsep Rubu' Mujayyab serta dapat mengakomodir konsep Rubu' Mujayyab. ${ }^{1}$ Kegunaan yang ada, merupakan pengaplikasian dari perhitungan astronomis. Satu fungsi saling berkaitan dengan fungsi lain. Misal, penentuan lintang dan bujur erat kaitannya dengan penentuan arah kiblat, penentuan deklinasi Matahari dengan penentuan arah kiblat dengan Matahari, penentuan awal waktu sholat dan penentuan awal bulan qomariyah.

Deklinasi adalah jarak suatu benda langit ke equator langit, diukur melalui lingkaran waktu (lingkaran deklinasi) atau dapat juga dikatakan deklinasi adalah sepotong busur lingkaran deklinasi yang diukur dari titik perpotongan suatu benda langit ke equator langit pada lingkaran deklinasi. Deklinasi yang berada di sebelah utara equator diberi tanda (+) dan bernilai positif, sedangkan yang berada di sebelah selatan equator diberi tanda (-) bernilai negatif.

Deklinasi Matahari selalu berubah-ubah dari waktu ke waktu selama satu tahun, tetapi pada tanggal-tanggal tertentu yang sama; deklinasi Matahari kira-kira sama pula. Deklinasi positif mulai tanggal 21 Maret sampai dengan tanggal 23 September, dari tanggal 23 September sampai tanggal 21 Maret deklinasi negatif. Setelah tanggal 21 Maret Matahari bergerak secara perlahan dari equator kearah utara dan semakin lama semakin jauh jaraknya dari equator dan pada tanggal 22

${ }^{1}$ M. Ihtirozun Ni'am, "Pemanfaatan I-zun Dial dalam Kajian Ilmu Falak", Makalah Disampaikan dalam Acara Diskusi Ilmiah, Menyambut Istiwa'ul A'dham dan Launching I-zun Dial 2015. Di Masjid Al Fitroh Kampus 2 UIN Walisongo Semarang, 27 Mei 2015 
Juni Matahari mencapai titik terjauh perjalanannya ke utara yaitu sebesar $231 / 2^{\circ} .^{2}$ Kemudian berbalik arah dari utara ke equator secara perlahan, semakin lama semakin dekat equator dan pada tanggal 23 September kedudukannya tepat di ekuator kembali. Dari tanggal 23 September Matahari terus bergerak menuju arah Selatan, semakin lama semakin jauh pada tanggal 22 Desember Matahari mencapai titik terjauh kedudukannya dari equator, yaitu sebesar $2312^{\circ}$ Selatan. Lalu berbalik arah menuju ke equator bergerak secara perlahan semakin lama semakin mendekati equator dan pada tnaggal 21 Maret kedudukan Matahari tepat di equator kembali.

Dengan demikian, pergerakan Matahari selama 6 bulan berada di selatan khatulistiwa. Tiga bulan pertama Matahari bergerak dari khatulistiwa kearah utara dan selatan sampai mencapai titik terjauh (tanggal 22 Juni untuk arah utara dan tanggal 22 Desember untuk arah selatan), tiga bulan kedua Matahari bergerak dari utara dan selatan menuju khatulistiwa (tanggal 21 Maret dan 23 September dalam setiap tahun). ${ }^{3}$

Berdasarkan permasalahan di atas, maka fokus pembahasan adalah: (1) metode penentuan deklinasi Matahari dengan menggunakan I-zun Dial dan (2) Akurasi metode penentuan deklinasi Matahari dengan menggunakan I-zun Dial.

Deklinasi dalam bahasa Inggris disebut Declination. Tanda astronomi huruf Yunaninya "delta" $(\delta)$ yaitu jarak suatu benda langit dari equator dihitung sepanjang lingkaran waktu/lingkaran deklinasi hingga benda langit tersebut. Kalau benda langit ada di sebelah utara equator, maka tandanya positif, sedang kalau di selatan equator tanda deklinasinya negative. ${ }^{4}$

Deklinasi Matahari dapat ditentukan salah satunya dengan menggunakan alat yang bernama I-zun Dial. Dalam menentukan nilai deklinasi Matahari dengan I-zun Dial, terlebih dahulu harus mempersiapkan beberapa data yang dibutuhkan, antara lain lintang tempat, panjang gnomon (panjang tongkat yang digunakan

\footnotetext{
${ }^{2}$ Susiknan Azhari, Ensiklopedi Hisab Rukyat, (Yogyakarta : Pustaka Pelajar, 2008), hlm. 54

${ }^{3}$ A. Jamil, Ilmu Falak (Teori dan Aplikasi), (Metro : Amzah, 2009), hlm.15

${ }^{4}$ Mudabarah Al-I’tidaalain, tanpa keterangan. Hlm.11
} 
dalam praktik atau tongkat istiwa) ${ }^{5}$, panjang bayangan saat kulminasi dan arah bayangan (hanya ada dua kemungkinan, yaitu utara dan selatan).

Langkah-langkah untuk menentukannya adalah : 6

1. Tentukan arah utara sejati dan letakkan angka 0 pada I-zun Dial berhimpit pada arah tersebut,

2. Ketika bayangan dari gnomon sudah mengarah ke utara atau selatan saat kulminasi tempat, lihatlah berapa panjang bayangannya,

3. Hitunglah nilai Jarak Zenith Matahari (ZM) dengan rumus :

\section{Tan ZM = Panjang Bayangan / Panjang Gnomon}

4. Perhatikan pula ke mana arah bayangannya, apakah ke selatan atau ke utara,

5. Apabila bayangan mengarah ke utara, maka :

Nilai deklinasi adalah jarak Zenith Matahari dikurangi nilai lintang tempat, apabila arah bayangan ke utara, maka:

\section{Deklinasi Matahari = Jarak Zenith Matahari - Lintang Tempat}

Namun apabila bayangan Matahari mengarah ke selatan, maka nilai deklinasi adalah jarak Zenith Matahari ditambah nilai lintang tempat.

\section{Deklinasi Matahari $=$ Jarak Zenith Matahari + Lintang Tempat}

Pada hakikatnya, data deklinasi Matahari dapat dengan mudah dilihat pada Ephemeris ataupun Almanak Nautika, keduanya merupakan data yang akurat. Almanak Nautika adalah data yang dijadikan sumber oleh Badan Hisab Rukyat Departemen Agama terutama untuk keperluan menghisab awal bulan kamariyah. Penggunaannya bukan tanpa alasan, karena data yang dihasilkan sangat akurat, mengingat bahwa data Almanak Nautika dihasilkan oleh lembaga-lembaga Astronomi Internasional yang telah menggunakan alat optik canggih, lembaga tersebut diantaranya Her Majesty's Nautical Almanac Office, Royal Naval Observatory dan United State Naval Observatory, keduanya merupakan lembaga-

${ }^{5}$ Tongkat istiwa adalah sebuah tongkat yang ditancapkan tegak lurus pada bidang datar dan diletakkan pada tempat terbuka, sehingga Matahari dapat menyinarinya dengan bebas. Pada zaman dahulu tongkat ini dikenal dengan nama gnomon. Lihat Ahmad Izzuddin, Ilmu Falak Praktis: Metode Hisab-Rukyah Praktis dan Solusi Permasalahannya, (Semarang: Pustaka Rizki Putra, 2012), hlm. 65.

${ }^{6}$ M. Ihtirozun Niam. Penemu I-zun Dial, Wawancara Pribadi, Ponpes Al Firdaus Semarang, 5 April 2016. 
lembaga bertaraf Internasional yang sudah tersertifikasi dan sangat ahli dalam Bidang Astronomi. Selain itu Almanak Nautika juga telah terbukti akurat untuk membantu pelaut dalam hal Navigasi, terutama ketika di laut yang jauh dari daratan. Dengan demikian maka penentuan tempat kedudukan kapal hanya dapa diketahui dengan mengukur tingginya benda angkasa yang terlihat. ${ }^{7}$

Tidak jauh berbeda dengan Almanak Nautika, Ephemeris juga tak kalah akurat. Berlatar belakang dari penelitian yang dikembangkan oleh Departemen Pertahanan Amerika Serikat dengan menggunakan sistem pemosisi global yang mengacu pada NAVSTAR Global Positioning System (GPS) pada satelit yang mengorbit pada bumi. Sistem yang digunakan, menggunakan sejumlah satelit yang berada di orbit bumi yang memancarkan sinyalnya ke bumi dan ditangkap oleh sebuah alat penerima, didalamnya terdapat tiga bagian inti yaitu bagian kontrol, bagian angkasa dan bagian pengguna. Sinyal-sinyal dari dari satelit diterima oleh bagian kontrol, dikoreksi dan dikirimkan kembali ke satelit. Koreksi data yang tepat dari satelit kemudian disebut dengan data Ephemeris. ${ }^{8}$

\section{Bagian-bagian I-zun Dial}

Di bawah ini merupakan bagian-bagian dari I-zun Dial serta fungsinya:

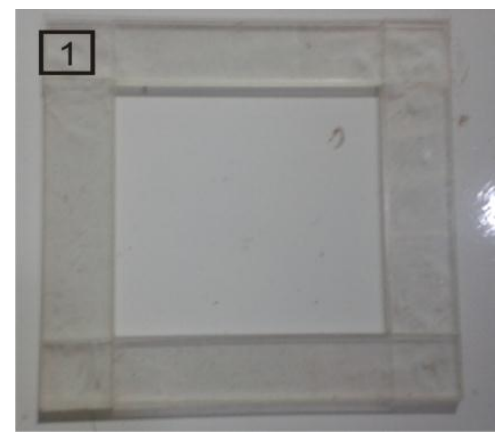

\section{Gambar 2. Penyangga}

a. 1 (Penyangga) : Menjaga agar bidang dial senantiasa stabil, tidak bergerak-gerak saat tertiup angin.

\footnotetext{
7 Imas Musfiroh, "Hisab Awal Bulan Kamariyah (Studi Komparasi Sistem Hisab Almanak Nautika dan Astronomical Algorithms Jean Meeus)" Tesis Pascasarjana Magister Ilmu Falak (Semarang : IAIN Walisongo, 2014), hlm 54-55.

${ }^{8}$ https: // id.wikipedia.org/wiki/Sistem_Pemosisi_Global, diakses pada 3 November 2016 pukul 21.16 .
} 
ELFALAKY: Jurnal Ilmu Falak

Vol. 3. Nomor 2. Tahun 2019 M / 1441 H

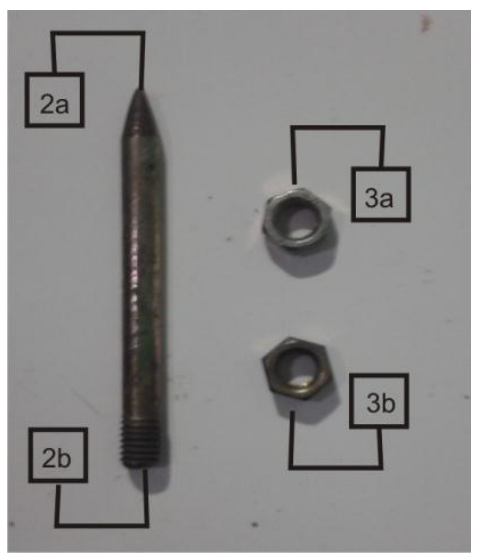

Gambar 3. Gnomon dan Nut

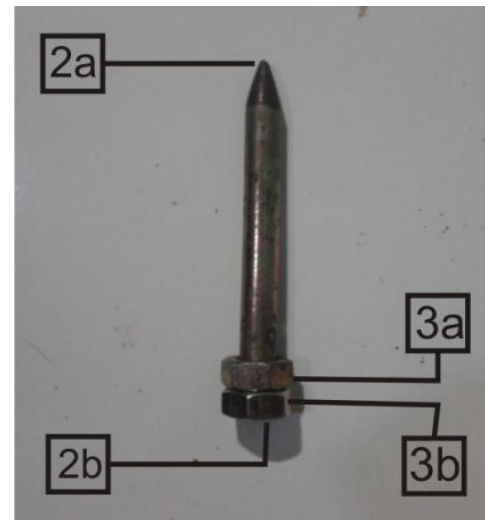

Gambar 4. Gnomon dan Nut saat disatukan

b. 2a (Gnomon atas) \& 2b (Gnomon bawah) : Semacam bolt yang dapat dipasang nut dan dapat membentuk bayangan pada bidang dial. Caranya yakni dengan melepas $3 \mathrm{~b}$ terlebih dahulu kemudian memasukkan $2 \mathrm{a}$ pada lubang di tengah bidang dial dan mengunci $2 \mathrm{a}$ dengan $2 \mathrm{~b}$ dari bawah menggunakan $3 b$.

c. 4 (Khoit)

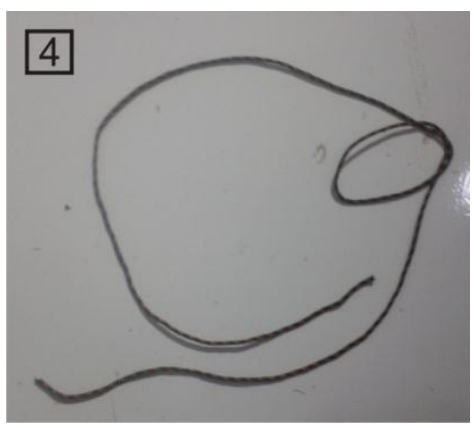

Gambar 5. Khoit 
Bagian ini berfungsi untuk menyesuaikan ujung bayangan pada angka yang tertera dalam bidang dial bila panjang bayangan belum mengenai angka pada bidang dial atau melebihinya. Ini juga bisa dipakai untuk menghubungkan 2 titik yang mengenai lingkaran saat penentuan arah utara sejati dengan metode sebelum dan sesudah kulminasi.

d. 5 (Bidang Dial) : Mengambil data dari observasi

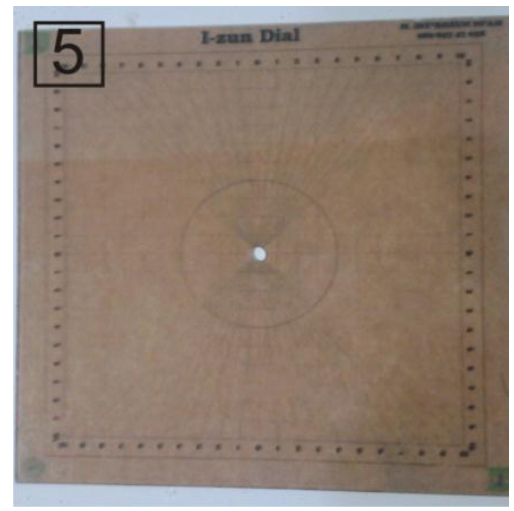

\section{Gambar 6. Bidang Dial}

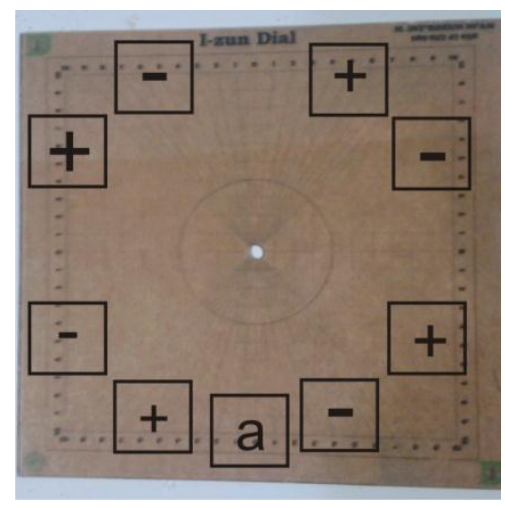

\section{Gambar 7. Bidang dial}

1) (angka bidang dial) : tempat pemosisian bayangan, arah kiblat, arah hilal, atau arah objek observasi lainnya. Terdapat 4 titik 0. Angka yang berada di sebelah kiri 0 bernilai negatif (-), sedangkan yang berada di sebelah kanan 0 bernilai positif (+). Angka bidang dial ini mempunyai ketelitian sampai pada milimeter $(\mathrm{mm})$

2) (pusat bidang dial): tempat memasang gnomon

3) (lingkaran bidang dial) : menentukan arah utara sejati dengan metode observasi sebelum dan sesudah kulminasi. 


\section{Pembahasan}

Pentingnya beberapa sub-fungsi dalam pengaplikasian I-zun Dial tidak terlepas dari praktik pengukuran yang dilakukan dilapangan sekalipun tentunya tidak terlepas dari beberapa keterbatasan tertentu. Oleh sebab itu beberapa hal perlu diperhatikan secara mendalam oleh peneliti dalam penggunaan dan pengaplikasiannya mengingat I-zun Dial merupakan instrumen falak non optic yang penggunaannya sangat membutuhkan kecermataan dari penggunanya dan tentunya tidak luput akan kesalahan manusia (human error). Sesuai hasil pengamatan peneliti, beberapa factor perlu diperhatikan terutama dalam kondisi penggunaannya untuk menentukan deklinasi Matahari, yaitu:

a. Ketergantungan terhadap ketersediaan cahaya Matahari (Cuaca)

Objek pengamatan I-zun Dial adalah Matahari, dan dalam metodenya, sekalipun secara praktis menggunakan perhitungan matematis, namun cara memperoleh datanya tidak terlepas dari cahaya Matahari. Hal ini adalah faktor utama dan kebutuhan utama I-zun Dial dalam penentuan deklinasi Matahari. Apabila cuaca tidak bersahabat, sangat dimungkinkan bahwa hasil pengaplikasian akan kurang memuaskan, kurang akurat, tidak akurat atau bahkan sama sekali tidak dapat dilakukan pengaplikasian sama sekali. Tidak dapat dipungkiri bahwa hal ini sulit untuk diatasi, namun bisa dicari jalan keluar yaitu dengan observasi perkiraan cuaca, baik melalui aplikasi prakiraan cuaca, atau melalui media yang dapat kita ketahui sejak beberapa hari sebelum hari pelaksanaan. Hal ini penting agar pengaplikasian dapat membuahkan hasil yang memuaskan.

b. Kedataran Tempat

Dalam analisis penulis, I-zun Dial cukup rentan dengan human eror terutama karena faktor datar/tidaknya bidang tempat diletakkannya I-zun Dial. Alat ini membutuhkan bantuan waterpass untuk memastikan bahwa I-zun Dial dalam posisi datar, sekalipun pada bidang-bidang yang sebelumnya dibangun dengan bidang datar, seperti lantai, hal ini juga berfungsi sebagai verifikasi datar tidaknya tempat observasi agar tidak mempengaruhi posisi dan kemiringan antara gnomon sebagai penunjuk panjang bayangan Matahari dan 
bidang dial sebagai penanda panjang bayangan yang ditunjukkan oleh bayangan Matahari tersebut karena harus di ingat, elemen penting dalam metode penentuan deklinasi Matahari dengan menggunakan I-zun Dial adalah data bayangan gnomon yang dihasilkan oleh cahaya Matahari.

c. Keterjangkauan terhadap Cahaya Matahari

Berbeda dengan faktor pertama yaitu pengaruh cuaca terhadap bayangan benda yang merupakan refleksi atas cahaya Matahari, faktor keterjangkauan terhadap cahaya Matahari lebih dipengaruhi oleh pemilihan tempat observasi. Harus dipastikan bahwa tempat observasi tidak terhalang oleh suatu benda besar, sekalipun menurut penulis, pengaplikasian I-zun Dial tidak harus dilakukan pada tempat yang luas dan lapang seperti lapangan. Hal ini disebabkan karena selain fungsi untuk menentukan deklinasi Matahari, Izun Dial juga mempunyai fungsi lainnya. Cukup pastikan bahwa tempat pengamatan tidak terhalang oleh benda lain disekitarnya dan juga tidak terlewati oleh benda yang dapat membelokkan cahaya Matahari.

d. Standar Waktu

Hal ini juga sangat penting, terutama harus diperhatikan sebelum melakukan pengamatan. Terlebih dahulu pengamat harus melakukan checking dan setting waktu (jam) agar sesuai dengan standar. Jam yang dipakai hendaknya sudah standar dan akurat agar waktu yang ditampilkan bisa sampai pada ukuran detik. Untuk memperoleh waktu yang akurat bisa melihat pada Global Positioning System (GPS), atau yang lebih mudah dan praktis adalah dengan cara mengakses http://www.greenwhichmeantime.com dengan internet online.

e. Panjang Bayangan

Panjang bayangan yang dimaksudkan adalah ketelitian, ketepatan dan keakuratan pemantau dalam menulis/record data panjang bayangan Matahari. Hal ini harus sedetail mungkin hingga satuan ukuran millimeter. Jika bayangan yang dihasilkan menunjukkan angka 3,7 maka harus tepat menulis 3,7. Tidak berlaku pembulatan ke atas atau kebawah demi hasil pengamatan yang akurat. 
Serta yang menjadi cukup penting adalah ketika panjang bayangan berada pada ukuran kira-kira $0,1 \mathrm{~mm}$ hingga $0,5 \mathrm{~mm}$ bayangan akan sangat sulit untuk teramati karena tertutup oleh bayangan nut. Solusi memperpanjang gnomon bisa diaplikasikan sekalipun pasti akan terjadi panjang bayangan kurang dari $-0,5 \mathrm{~mm}$ tersebut.

\section{Analisis Konstruksi dan Struktur I-zun Dial}

Beberapa komponen yang tersusun sehingga menjadi I-zun Dial sangat praktis dan dapat dengan mudah dibawa, terdiri dari:

a. Nama Komponen : Bidang Dial

Bahan : 1 Kayu

\section{Akrilik}

Berdasar pada hasil wawancara penulis dengan penemu I-zun Dial, alat ini sengaja di desain berbentuk persegi pada bidang dialnya, bukan lingkaran atau bentuk lain karena agar dapat digunakan untuk melokalisir objek rukyah atau benda langit sehingga menjadikannya berbeda dengan alat-alat lain sebelumnya.

I-zun Dial memiliki dua varian, salah satu yang menjadi pembedanya adalah bidang dialnya (panjang sisi 20 x $20 \mathrm{~cm}$ ), yaitu ada yang terbuat dari kayu, ada juga yang terbuat dari akrilik. Bahan kayu mempunyai kelebihan yaitu cukup kuat, dalam ukuran tertentu juga tidak mudah mengalami perubahan struktur dan bentuk, semisal membengkok. Sementara bahan ini mempunyai kelemahan yaitu lebih berat dari bahan akrilik, rentan jika terkena goresan, rentan dengan api, rayap dll.

Sementara itu, bahan akrilik juga rentan dengan kerusakan yang dipicu oleh api, panas, atau patah karena perawatan yang kurang baik. Selain itu bahan akrilik juga rentan terhadap perubahan bentuk bidang dial yaitu mudah bengkok. Namun bahan ini mempunyai kelebihan antara lain adalah ringan, transparan dan memudahkan pengamatan salah satunya pada pengamatan hilal dan ketinggian benda langit. Berhubung bahan akrilik ini transparan, maka ketika bidang dial digunakan untuk mengamati 
bayangan, pengamat harus menyediakan alas polos seperti kertas agar bayangan teramati dengan jelas dan tidak kabur.

b. Nama Komponen : Ukuran Satuan (Melekat pada bidang dial)

Bahan : Tinta (Stiker)

Cukup memudahkan penggunanya dikarenakan ukuran satuan yang tertera dalam bidang dial adalah satuan centimeter dan millimeter yang juga mempunyai fungsi sebagai penggaris ketika bayangan muncul, sudah disediakan pula garis-garis untuk mengukurnya. Izun tidak memakai satuan derajat $\left(^{\circ}\right)$, namun lebih memilih cm karena apabila dipakai untuk keperluan menghitung azimuth Matahari, azimuth kiblat atau hal-hal lainnya yang memakai satuan derajat perlu dirubah terlebih dahulu nilai dalam derajat itu kedalam cm dengan konsep perhitungan segitiga. Dengan demikian, penghapusan nilai derajat atau menit bisa lebih diminimalisir.

Sedangkan perpaduan antara tinta dan bidang dial akrilik cukup memerlukan perawatan intensif, karena tinta akan sangat mudah mengelupas, beda dengan stiker yang dilekatkan pada bidang dial bahan kayu. Terkelupasnya tinta juga bisa menghambat penghitungan.

c. Nama Komponen : Tongkat Gnomon dan Nut

Bahan : Besi

Tongkat Gnomon dan Nut adalah komponen sederhana namun sangat penting keberadaannya. Tongkat gnomon ini mempunyai ukuran panjang yang cukup beragam. Terkait bahan, dirasa sudah cukup cocok dan ideal.

d. Nama Komponen : Tali (Khoit)

Bahan : Menyesuaikan

Tali (khoit) digunakan untuk membuat garis lurus bantuan terhadap refleksi benda/gnomon.

e. Nama Komponen : Penyangga (untuk bidang dial akrilik)

Bahan : Akrilik

Penyangga ini digunakan agar bidang dial tetap berada pada posisi datar, terbuat dari akrilik penyangga ini berbentuk persegi. Namun 
bahannya yang berasal dari akrilik, disara kurang kuat dan cukup rentan akan terjadinya patah, terlebih saat ini penyangga yang ada disatukan hanya menggunakan lem yang juga cukup mudah lepas. ${ }^{9}$

\section{Analisis Akurasi I-zun Dial dalam Penentuan Deklinasi Matahari}

Penelitian ini menggunakan bahan data pembanding yang peroleh dari Almanak Nautika dan Ephemeris $2016^{10}$. Almanak Nautika adalah data astronomi yang dikeluarkan oleh badan antariksa Amerika Serikat dalam kurun waktu satu tahun sekali. Di dalam Almanak Nautika ini termuat tentang daftar deklinasi, equation of time, waktu terbit dan tenggelamnya Matahari dan bulan, dan lain sebagainya yang berhubungan dengan data benda-benda langit. ${ }^{11}$ Tingkat akurasi Almanak Nautika terbilang cukup akurat karena resmi dikeluarkan oleh badan Astronomi Amerika Serikat yang diketahui cukup moderen dalam hal peralatan pengamatan benda langit. Almanak Nautika juga tidak diperjualbelikan, sementara itu di masa lalu, cukup susah untuk mendapatkannya dan bisa diperoleh dari TNI AL Republik Indoneisa, namun saat ini dapat secara mudah di akses untuk banyak keperluan pengembangan ilmu astronomi. Dalam hal ini fungsi alatalat canggih yang menghasilkan data dalam Almanak Nautika yang penulis gunakan sebagai patokan atau parameter hasil perhitungan nilai deklinasi Matahari yang dihasilkan oleh I-zun Dial.

Ada juga alternative lain yaitu menggunakan software Winhisab yang didalamnya mengadopsi data-data dari ephemeris. Software ini menjadi populer lantaran hisab sistem ephemeris saat ini telah menjadi metode perhitungan falak kontemporer yang paling banyak digunakan. Dibanding metode hisab kontemporer lainnya, data astronomis untuk metode ini lebih mudah didapatkan. Hal tersebut tidak terlepas dari peran Kementerian Agama Republik Indonesia (Kemenag RI) yang menerbitkan buku Ephemeris Hisab-Rukyah yang berisi data ephemeris untuk metode ini setiap tahunnya. Kemenag juga mengeluarkan

\footnotetext{
${ }^{9}$ Lihat selengkapnya gambar koponen I-zun Dial pada Bab III di bagian komponen

10 Terkait tingkat akurasi Almanak Nautika dan Ephemeris, sebelumnya sudah dijelaskan pada BAB I, Sub Bab Kerangka Teoritik hlm 10-12.

${ }^{11} \mathrm{http}: / /$ my-dock.blogspot.com/\#ixzz4LbBy8JeQ diakses pada 14 September 2016.
} 
software WinHisab yang merupakan software perhitungan data ephemeris Matahari dan Bulan. Software ini cukup ringan dan praktis karena dapat digunakan secara offline dan tanpa proses instalasi yang rumit.

Sementara itu, uji akurasi I-zun Dial ini dirasa cukup penting mengingat I-zun Dial merupakan instrumen baru dan perangkat aplikatif yang praktis dalam menentukan nilai deklinasi dibandingkan peralatan lain. Akurasi sendiri merupakan ketepatan, kecermatan, ketelitian, kejituan dan keakuratan. ${ }^{12}$ Jika dipandang dari sudut fungsional, salah satu kegunaan dari data yang dihasilkan oleh I-zun Dial sama dengan data yang dihasilkan peralatan canggih dalam Almanak Nautika maupun Ephemeris Hisab Rukyat.

Guna melakukan pengujian tingkat akurasi penentuan nilai deklinasi Matahari oleh I-zun Dial maka perlu dilaksanakan penelitian di suatu tempat Dalam hal ini penulis melakukan pengamaatan di tempat terbuka, dengan hasil penelitian sebagai berikut:

Tabel Hasil selisih perhitungan nilai deklinasi Matahari pukul 19.00 GMT+7 dan pukul 12.00 pada Almanak Nautika dan Ephemeris

\begin{tabular}{|c|c|c|c|c|}
\hline \multirow{2}{*}{$\begin{array}{l}\text { Deklinasi } \\
\text { Matahari } \\
\text { I-zun Dial }\end{array}$} & \multicolumn{2}{|c|}{ Pembanding I } & \multicolumn{2}{|c|}{ Pembanding II } \\
\hline & $\begin{array}{l}\text { Almanak } \\
\text { Nautika }^{13}\end{array}$ & Selisih & Ephemeris $^{14}$ & Selisih \\
\hline \multicolumn{5}{|c|}{12 September 2016} \\
\hline $3^{\circ} 15^{\prime} 0,43^{\prime \prime}$ & $3^{\circ} 54,1^{\prime}$ & $0^{\circ} 39^{\prime} 5,57^{\prime \prime}$ & $3^{\circ} 54,{ }^{\prime} 08^{\prime \prime}$ & $0^{\circ} 39^{\prime} 7,57^{\prime \prime}$ \\
\hline \multicolumn{5}{|c|}{21 September 2016} \\
\hline $0^{\circ} 13^{\prime} 25,54^{\prime \prime}$ & $0^{\circ} 25,6^{\prime}$ & $0^{\circ} 12^{\prime} 10,46^{\prime \prime}$ & $0^{\circ} 25^{\prime} 39^{\prime \prime}$ & $0^{\circ} 12^{\prime} 13,46^{\prime \prime}$ \\
\hline \multicolumn{5}{|c|}{27 September 2016} \\
\hline$-2^{\circ} 4^{\prime} 24,48^{\prime \prime}$ & $-1^{\circ} 54,5^{\circ}$ & $0^{\circ} 9^{\prime} 54,48^{\prime \prime}$ & $-1^{\circ} 54^{\prime} 30^{\prime \prime}$ & $0^{\circ} 9^{\circ} 54,48^{\prime \prime}$ \\
\hline \multicolumn{5}{|c|}{5 Oktober 2016} \\
\hline$-4^{\circ} 46^{\prime} 37,59^{\prime \prime}$ & $-5^{\circ} 0,4^{\prime}$ & $0^{\circ} 13^{\prime} 46,41^{\prime \prime}$ & $-5^{\circ} 0^{\prime} 20^{\prime \prime}$ & $0^{\circ} 13^{\prime} 42,41^{\prime \prime}$ \\
\hline \multicolumn{5}{|c|}{16 Oktober 2016} \\
\hline$-9^{\circ} 15^{\prime} 10,4^{\prime \prime}$ & $-9^{\circ} 08,6^{\prime}$ & $0^{\circ} 6^{\prime} 34,4^{\prime \prime \prime}$ & $-9^{\circ} 08^{\circ} 36^{\prime \prime}$ & $0^{\circ} 6^{\prime} 34,4^{\prime \prime}$ \\
\hline
\end{tabular}

Sebuah program yang ditulis untuk satu tujuan, mungkin tidak cocok untuk tujuan yang lainnya, serta keakuratan yang dibutuhkan dalam perhitungannya

${ }^{12}$ M.dahlan Y. al-Barry dan L. Lya Sofyan Yacub, Kamus Istilah Popular, (Surabaya: Target Press, 2003), hlm 26. 
sangat erat kaitannya pada tujuannya. ${ }^{13}$ Sementara itu untuk mengetahui akurasi $I$ zun Dial dalam menentukan nilai deklinasi Matahari penulis kemudian melakukan perhitungan waktu sholat Isya yang hasilnya ditunjukkan pada tabel di bawah ini:

\section{Tabel 4.22. Hasil selisih perhitungan waktu sholat Isya I-zun Dial, Almanak Nautika dan Ephemeris ${ }^{14}$}

\begin{tabular}{|l|c|c|c|c|c|c|} 
Tanggal & \multirow{2}{*}{ (Lintang \& Bujur) } & & Nautika & \multicolumn{2}{|c|}{} \\
\cline { 3 - 7 } & & $\mathrm{A}$ & $\mathrm{B}$ & $\mathrm{C}$ & $\mathrm{A}-\mathrm{B}$ & $\mathrm{A}-\mathrm{C}$ \\
\hline $12-09-16$ & $6^{\circ} 54^{\prime} 3.65^{\prime \prime} \mathrm{LS}$ & $18: 51: 44,13$ & $18: 52: 7,4$ & $18: 52: 7,42$ & $0: 0: 23,27$ & $0: 0: 23,29$ \\
\hline & $109^{\circ} 40^{\prime} 19.93^{\prime \prime} \mathrm{BT}$ & $18: 53$ & $18: 54$ & $18: 54$ & 1 menit & 1 menit \\
\hline $21-09-16$ & $6^{\circ} 54^{\prime} 3.65^{\prime \prime} \mathrm{LS}$ & $18: 46: 51,16$ & $18: 46: 57,46$ & $18: 46: 57,48$ & $0: 0: 6,3$ & $0: 0: 6,32$ \\
\hline & $109^{\circ} 40^{\prime} 19.93^{\prime \prime} \mathrm{BT}$ & $18: 48$ & $18: 48$ & $18: 48$ & Tidak ada & Tidak ada \\
\hline $27-09-16$ & $6^{\circ} 54^{\prime} 3.65^{\prime \prime} \mathrm{LS}$ & $18: 45: 46,7$ & $18: 45: 40,91$ & $18: 45: 41,18$ & $0: 0: 5,79$ & $0: 0: 5,52$ \\
\hline & $109^{\circ} 40^{\prime} 19.93^{\prime \prime} \mathrm{BT}$ & $18: 47$ & $18: 47$ & $18: 47$ & Tidak ada & Tidak ada \\
\hline $5-10-16$ & $6^{\circ} 59^{\prime} 44,35^{\prime \prime} \mathrm{LS}$ & $18: 42: 9,25$ & $18: 42: 18$ & $18: 42: 17,96$ & $0: 0: 8,75$ & $0: 0: 8,71$ \\
\hline & $110^{\circ} 21^{\prime} 10.31^{\prime \prime} \mathrm{BT}$ & $18: 44$ & $18: 44$ & $18: 44$ & Tidak ada & Tidak ada \\
\hline $16-10-16$ & $6^{\circ} 54^{\prime} 3.65^{\prime \prime} \mathrm{LS}$ & $18: 45: 4,44$ & $18: 44: 59,55$ & $18: 44: 59,55$ & $0: 0: 4,89$ & $0: 0: 4,89$ \\
\hline & $109^{\circ} 40^{\prime} 19.93^{\prime \prime} \mathrm{BT}$ & $18: 47$ & $18: 46$ & $18: 46$ & 1 menit & 1 menit \\
\hline
\end{tabular}

Berdasarkan analisis I-zun Dial, Almanak Nautika dan Ephemeris tersebut di atas, data yang ditampilkan dari ketiganya untuk waktu sholat Isya menunjukkan adanya perbedaan, namun masih dalam batas toleransi . Ketika data nilai deklinasi yang dihasilkan oleh I-zun Dial, Almanak Nautika dan Ephemeris diaplikasikan dalam perhitungan waktu sholat seperti tabel 4.22 di atas, dan hal ini menunjukkan keakuratannya.

${ }^{13}$ Ing. Khafid, Terjemahan Astronomical Alghorithms Jean Meeus : Modul kuliah Astronomi Pascasarjana,( tp, tt,) hlm. 19

14 Data diperoleh dari perhitungan manual penulis sementara tabel berwarna kuning merupakan hasil perhitungan waktu sholat Isya ditambah ihtiyath 2 menit 
Jika melihat pada perhitungan Ing. Khafid yang mengacu pada teori akurasi Jean Meeus bahwa keakuratan yang dibutuhkan dalam perhitungan waktu shalat berbeda dengan yang diperlukan untuk perhitungan awal bulan kalender Hijriyah. Untuk menghitung posisi Matahari dengan tujuan memperoleh waktu terbit, transit dan terbenam, akurasi 0.01 derajat $/\left(0^{\circ} 0^{\prime}\right.$ 36") sudah memadai. Alasannya jelas: gerakan harian tampak dari bola langit bersesuaian dengan rotasi lebih dari satu derajat selama interval waktu empat menit, dan kesalahan 0.01 derajat pada posisi objek akan menghasilkan kesalahan hanya 0.04 menit (kurang-lebih) dalam perhitungan waktu terbit dan terbenamnya. Dengan menggunakan ratusan komponen periodik ke dalam perhitungan untuk mendapatkan posisi Matahari dengan akurasi 0".01 hanya akan menjadi membuang-buang tenaga dan waktu pemrosesan komputer untuk masalah ini. ${ }^{15}$

\section{Simpulan}

Jika mengacu pada beberapa pembahasan dan analisis yang telah dilakukan pada bab sebelumnya, maka peneliti dapat menyimpulkan sebagai berikut :

1. Metode penentuan nilai deklinasi Matahari menggunakan I-zun Dial merupakan metode praktis untuk :
a. Menentukan waktu kulminasi tempat
b. Menentukan arah utara sejati
c. Menghitung nilai jarak zenith Matahari, dan yang terakhir
d. Menghitung nilai deklinasi Matahari.

Deklinasi Matahari dalam konsep I-zun Dial, didalamnya ditambahkan suatu ketentuan yang belum terungkap dalam kajian-kajian sejenis sebelumnya, atau dikategorikan merupakan ketentuan baru. Sedangkan untuk penggunaan I-zun Dial perlu adanya ketelitian bagi pengamat mengingat I-zun Dial termasuk instrumen falak non optik dan manual yang penggunaannya tidak terlepas dari kesalahan manusia (human error) dalam beberapa hal terkait seperti: waktu standar, kedataran tempat, tempat yang

15 Ing. Khafid, Telaah Pedoman Baku Hisab Jadwal Shalat. (Cibinong: Badan Informasi Geospasial, 2013) hlm. 4 
terjangkau Matahari, pembidikan panjang bayangan, dan pengaturan pemusatan titik koordinat tempat.

2. Akurasi metode penentuan nilai deklinasi Matahari menggunaan I-zun Dial dikategorikan akurat, karena jika data nilai deklinasi Matahari yang ditampilkan I-zun Dial dibandingkan dengan data Almanak Nautika dan Ephemeris, setelah melalui proses pengujian menunjukkan selisih yang hanya berbeda pada nilai menitnya saja, dibuktikan dengan kesepuluh uji coba, semuanya menunjukkan selisih menit dengan minimal pada angka 2 menit hingga paling besar di angka 39 menit. 


\section{DAFTAR PUSTAKA}

Almanak Nautika 2016 terbitan Navsoft format pdf

Aplikasi Winhisab 2016.

Azhari, Susiknan. 2008. Ensiklopedi Hisab Rukyah. Yogyakarta: Pustaka Pelajar. http://my-dock.blogspot.com/\#ixzz4LbBy8JeQ/

http://wikipedia.co.id/

Izzuddin, Ahmad. 2012. Ilmu Falak Praktis: Metode Hisab-Rukyat Praktis dan Solusi Permasalahannya. Semarang : Pustaka Rizki Putra.

Jamil, A.. 2011. Ilmu Falak (Teori dan Aplikasi), Jakarta : Amzah.

Khafid, Ing. Tt. Terjemahan Astronomical Alghorithms Jean Meeus: Modul kuliah Astronomi Pascasarjana.

Khafid, Ing. 2013. Telaah Pedoman Baku Hisab Jadwal Shalat. Cibinong: Badan Informasi Geospasial.

M. Ihtirozun Niam. Penemu I-zun Dial, Wawancara Pribadi, Ponpes Al Firdaus Semarang.

M.dahlan Y. al-Barry dan L. Lya Sofyan Yacub. 2003. Kamus Istilah Popular, Surabaya: Target Press.

Mudabarah Al-I’tidaalain

Musfiroh, Imas. 2014. "Hisab Awal Bulan Kamariyah (Studi Komparasi Sistem Hisab Almanak Nautika dan Astronomical Algorithms Jean Meeus)" Tesis Pascasarjana Magister Ilmu Falak. Semarang : IAIN Walisongo.

Ni'am, M. Ihtirozun. 2015. Pemanfaatan I-zun Dial dalam Kajian Ilmu Falak, Makalah Disampaikan dalam Acara Diskusi Ilmiah, Menyambut Istiwa'ul A'dham dan Launching I-zun Dial 2015. Di Masjid Al Fitroh Kampus 2 UIN Walisongo Semarang. 